\title{
Pollen analysis of the post-emergence residue of Melipona (Melikerria) interrupta Latreille (Hymenoptera: Apidae) bred in the central Amazon region
}

\author{
Marcos Gonçalves Ferreira ${ }^{1,2}$ and Maria Lúcia Absy ${ }^{1}$
}

Submitted: 23 April, 2013. Accepted: 16 July, 2013

\begin{abstract}
We applied an "adapted" protocol for collecting and processing pollen grains in the pollen analysis of the post-emergence residue of Melipona (Melikerria) interrupta Latreille. The study was conducted at the Sant'Ana honey farm, located on the banks of the Solimões River, in the municipality of Manacapuru, in the state of Amazonas, Brazil, where a colony was monitored in October and November 2010. From that colony, 10 samples of post-emergence residue were collected. Unlike in the acetolysis method, there was no need to expose pollen grains to an acidic medium, because pollen loses its content during the larval digestive process. We identified 32 pollen types, from 19 botanical families, plus three undetermined pollen types. The most representative family was Fabaceae (Mimosoideae), with eight pollen types, Mimosa guilandinae being the most common species. Only the pollen of Miconia (Melastomataceae), with 74.10\%, was classified as a common pollen. We also found that the pollen of Mimosa pudica (Fabaceae: Mimosoideae) retained its content, indicating that not all resources furnished by workers are utilized by the larvae. The protocol applied here, despite omitting the acetolysis process, was efficient, providing full details of pollen contained in post-emergence residue.
\end{abstract}

Key words: stingless bees, palynology, pollen, floral resources

\section{Introduction}

The relationships between pollen-collecting bees and plants can be analyzed in an indirect and practical manner by analysis of the pollen load carried by foraging bees, thus allowing the spectrum of floral resources and its relative attractiveness to the colonies to be determined for a given period or habitat (Imperatriz-Fonseca et al. 1993). Likewise, knowledge of plant species based on pollen and nectar sources contributes to the characterization and origin of the resource used (Carvalho et al. 2001). When performed on a monthly basis, such analyses also provide valuable floral calendars for further studies (Luz et al. 2007) and contribute to maintaining bee pasture.

Recently, the palynological analysis of post-emergence residue has been successfully applied in studies of trophic resources accessed by solitary bees of the Centridini tribe (Dórea et al. 2009; Dórea et al. 2010). However, a number of studies have evaluated pollen collected by stingless bees in the central Amazon region. Those studies have involved the use of classical protocols for the collection of pollen foraged by bees, such from pollen pots (Absy et al. 1984; Rech \& Absy 2011a; Rech \& Absy 2011b), from nectar and honey samples (Absy et al. 1980) or, more commonly, from the pollen baskets of worker bees (Absy \& Kerr 1977; Marques-Souza et al. 1995; Marques-Souza 1996; Marques-Souza et al. 1996; Marques-Souza et al. 2002; Oliveira et al. 2009). In this context, palynology has become an important tool, supporting the processes related to the analysis and identification of pollen grains. Regardless of the method of collection, the most widely adopted chemical process is acetolysis, as described by Erdtman (1960), which exposes pollen grains to an acidic medium (acetic anhydride and sulfuric acid), destroying its content, allowing a better assessment of the morphological characteristics of the walls of pollen grains and consequently their identification. Other, simpler methods, as proposed by Wodehouse (1935), using only the preparation of fresh pollen grains without eliminating its content, provide rapid morphological results. However, the use of such methods hampers the visualization of exine details, which is necessary for the palynological identification.

The aim of this study was to apply an "adapted" protocol of collecting and preparing pollen contained in the post-emergence residue of the stingless bee Melipona

\footnotetext{
${ }^{1}$ Instituto Nacional de Pesquisas da Amazônia, Departamento de Botânica, Laboratório de Palinologia, Manaus, AM, Brazil

${ }^{2}$ Author for correspondence: mgfbio@yahoo.com.br
} 
interrupta (Melikerria) Latreille, in order to enable detailed analyses of the pollen grains, in order to make rapid and accurate identifications of the plant species in the diet of this bee.

\section{Material and methods}

The study was conducted at the Sant'Ana honey farm, located on the banks of the Solimões River $\left(03^{\circ} 17^{\prime} 08^{\prime \prime}\right.$; $60^{\circ} 27^{\prime} 54^{\prime \prime} \mathrm{W}$ ), in the municipality of Manacapuru, in the state of Amazonas, Brazil. We used a colony of Melipona interrupta, popularly known as jupará, widely distributed and kept in honey farms in the region, the honey of which is nationally renowned for its excellent flavor.

Sampling occurred during October and November 2010, when a colony was monitored, from the inside, and observed until the emergence of new bees. Then, with the aid of tweezers, we withdrew, from the bottom of the cell, the pellet containing the feces of newly emerged bees. We obtained ten samples of this post-emergence residue, whi$\mathrm{ch}$, in this species, is retained for only a matter of minutes, before it could be discarded by the colony. The ten samples were designated A1 through A10, respectively.

Each residue sample was placed in a separate Eppendorf tube and taken to the Palynology Laboratory of the Brazilian Instituto Nacional de Pesquisas da Amazônia (INPA, National Institute for Amazonian Research). Glacial acetic acid was added, and the samples were allowed to sit for at least $24 \mathrm{~h}$. Then, with the aid of a glass rod, we macerated the samples and strained them with a copper micrometric screen, separating the wax content from the pollen, and packed the former into test tubes. Thereafter, unlike the acetolysis method described by Erdtman (1960), the process followed three steps prior to assembly of the slides:

1. The content was centrifuged at $2500 \mathrm{rpm}$ for $5 \mathrm{~min}$, and the supernatant was put off.

2. Distilled water (3 $\mathrm{ml}$ ) and absolute alcohol (two drops) were added, after which the contents were stirred and again centrifuged at $2500 \mathrm{rpm}$ for $5 \mathrm{~min}$, and the supernatant was put off.

3. Glycerin water ( $3 \mathrm{ml}, 1: 1)$ was added, the content was stirred and again centrifuged at $2500 \mathrm{rpm}$ for $5 \mathrm{~min}$. After the supernatant had been discarded, the tubes were overturned on filter paper and sat for at least 30 min before slide mounting.

The slides were mounted using Kisser glycerin gelatin (Salgado-Labouriau 1973), then paraffinized, three permanent slides being prepared for each sample.

We measured and photographed pollen grains using a light microscope (Primo Star; Carl Zeiss Microimaging, Jena, Germany), with a micrometric eyepiece, coupled to a digital camera (PowerShot A650 IS; Canon U.S.A., Inc., Lake Success, NY, USA). We identified pollen types by making comparisons with specimens in the reference pollen collection of the INPA Laboratory of Palynology, as well as by consulting reference materials (Roubik \& Moreno 1991; Punt et al. 2007).

For quantitative analysis, we counted 500 pollen grains from each sample and the frequency of pollen grains, considering only the simple presence or absence of a pollen type in any of the samples, was classified in accordance with Novais et al. (2009), who established the following categories of frequency: very common ( $>75 \%)$; common ( $>50 \%$ to $\leq 75 \%)$; uncommon ( $>25 \%$ to $\leq 50 \%)$; rare $(\geq 5 \%$ to $\leq 25 \%)$; and very rare $(<5 \%)$.

\section{Results}

In the residue samples evaluated, we identified 32 pollen types, representing 19 botanical families, and three pollen types were undetermined. The most representative family in the study was Fabaceae (Mimosoideae), with eight pollen types, pollen of the species Mimosa guilandinae being present in all samples. Other pollen types, such as those of Alchornea (Euphorbiaceae), Schizolobium amazonicum (Fabaceae: Caesalpinioideae), Miconia (Melastomataceae) and Solanum type (Solanaceae), were also present in all samples (Tab. 1).

None of the pollen types were classified as very common. Overall, the most common pollen types were from Miconia species, with $74.10 \%$, the only genus whose pollen was classified as common, followed by those of Schizolobium amazonicum, with $11.98 \%$, and Vismia species, with $6.30 \%$, both of which were classified as rare, and Alchornea species, with $3.72 \%$, whose pollen, although classified as very rare, was present in nearly all samples. Some botanical families, such as Anacardiaceae, Aquifoliaceae, Arecaceae, Boraginaceae, Burseraceae, Malpighiaceae and Passifloraceae, were also well represented, although their pollen was classified as very rare, as were all remaining pollen types (Tab. 1, Fig. 1).

Of the pollen grains evaluated in this study, only three were indeterminate. Those grains were characterized as small to medium in size and 3-colporate, with exines ranging from psilate to perforated, collectively accounting for only $0.38 \%$ of the pollen evaluated, being also classified as a very rare pollen type (Tab. 1).

At the family level (Fig. 1), the greatest contributions to the composition of the residue samples were made by Melastomataceae (74\%), Fabaceae (13.42\%), Hypericaceae (6.3\%), Euphorbiaceae $(3.72 \%)$ and Solanaceae $(0.94 \%)$, indicating that these are main components of the Melipona interrupta trophic niche.

One interesting detail was observed in the pollen of Mimosa pudica, which was the only pollen considered "very small". In most of the samples, $M$. pudica pollen retained its content, because, unlike the other pollen types, it often passed through the digestive tract of the larvae without being digested (Fig. 2). 
Pollen analysis of the post-emergence residue of Melipona (Melikerria) interrupta Latreille

(Hymenoptera: Apidae) bred in the central Amazon region

Table 1. Presence and frequency of pollen types in samples of post-emergence residue of Melipona interrupta Latreille. October-November 2010, state of Amazonas, Brazil.

\begin{tabular}{|c|c|c|c|c|c|c|c|c|c|c|c|}
\hline FAMILY & $\mathrm{A} 1$ & A2 & A3 & $\mathrm{A} 4$ & A5 & A6 & A7 & A8 & A9 & $\mathrm{A} 10$ & Total (\%) \\
\hline \multicolumn{12}{|l|}{ Species/pollen type } \\
\hline \multicolumn{12}{|l|}{ ANACARDIACEAE } \\
\hline Tapirira guianensis & $\mathrm{x}$ & $\mathrm{x}$ & $\mathrm{x}$ & & & & & & & & \\
\hline \multicolumn{12}{|l|}{ AQUIFOLIACEAE } \\
\hline Ilex type & $\mathrm{x}$ & & & & & & & & & & \\
\hline \multicolumn{12}{|l|}{ ARECACEAE } \\
\hline Elaeis type & & & $\mathrm{x}$ & & & & & $\mathrm{x}$ & & & \\
\hline \multicolumn{12}{|l|}{ ASTERACEAE } \\
\hline Mikania type & $\mathrm{x}$ & $\mathrm{x}$ & $\mathrm{x}$ & & & & $\mathrm{x}$ & $\mathrm{x}$ & $\mathrm{x}$ & $\mathrm{x}$ & 0.10 \\
\hline \multicolumn{12}{|l|}{ BIGNONIACEAE } \\
\hline Tecoma type & $\mathrm{x}$ & $\mathrm{x}$ & $\mathrm{x}$ & $\mathrm{x}$ & $\mathrm{x}$ & & $\mathrm{x}$ & $\mathrm{x}$ & $\mathrm{x}$ & $\mathrm{x}$ & 0.18 \\
\hline \multicolumn{12}{|l|}{ BORAGINACEAE } \\
\hline Cordia type & & & $\mathrm{x}$ & $\mathrm{x}$ & $\mathrm{x}$ & & & $\mathrm{x}$ & $\mathrm{x}$ & & \\
\hline \multicolumn{12}{|l|}{ BURSERACEAE } \\
\hline Protium type & & $\mathrm{x}$ & $\mathrm{x}$ & & & & & & & $\mathrm{x}$ & \\
\hline \multicolumn{12}{|l|}{ EUPHORBIACEAE } \\
\hline Alchornea type & $\mathrm{x}$ & $\mathrm{x}$ & $\mathrm{x}$ & $\mathrm{x}$ & $\mathrm{x}$ & $\mathrm{x}$ & $\mathrm{x}$ & $\mathrm{x}$ & $\mathrm{x}$ & $\mathrm{x}$ & 3.72 \\
\hline \multicolumn{12}{|l|}{ FABACEAE/CAESALPINIOIDEAE } \\
\hline Hymenaea type & $\mathrm{x}$ & $\mathrm{x}$ & $\mathrm{x}$ & & $\mathrm{x}$ & $\mathrm{x}$ & $\mathrm{x}$ & & & & 0.36 \\
\hline Schizolobium amazonicum & $\mathrm{x}$ & $\mathrm{x}$ & $\mathrm{x}$ & $\mathrm{x}$ & $\mathrm{x}$ & $\mathrm{x}$ & $\mathrm{x}$ & $\mathrm{x}$ & $\mathrm{x}$ & $\mathrm{x}$ & 11.98 \\
\hline \multicolumn{12}{|l|}{ FABACEAE/MIMOSOIDEAE } \\
\hline Inga type & & & & & $\mathrm{x}$ & & & & & & \\
\hline Mimosa invisa & & $\mathrm{x}$ & & & $\mathrm{x}$ & $\mathrm{x}$ & & & & & 0.08 \\
\hline Mimosa guilandinae & $\mathrm{x}$ & $\mathrm{x}$ & $\mathrm{x}$ & $\mathrm{x}$ & $\mathrm{x}$ & $\mathrm{x}$ & $\mathrm{x}$ & $\mathrm{x}$ & $\mathrm{x}$ & $\mathrm{x}$ & 0.42 \\
\hline Mimosa asperata & & $\mathrm{x}$ & & & & & & & & $\mathrm{x}$ & 0.30 \\
\hline Mimosa pudica & & $\mathrm{x}$ & & $\mathrm{x}$ & & & & $\mathrm{x}$ & & $\mathrm{x}$ & 0.26 \\
\hline Mimosa spruceana & & $\mathrm{x}$ & & & & & $\mathrm{x}$ & $\mathrm{x}$ & & $\mathrm{x}$ & 0.02 \\
\hline Piptadenia type & & & & $\mathrm{x}$ & & & & $\mathrm{x}$ & $\mathrm{x}$ & $\mathrm{x}$ & \\
\hline Stryphnodendron guianense & $\mathrm{x}$ & & $\mathrm{x}$ & & $\mathrm{x}$ & $\mathrm{x}$ & $\mathrm{x}$ & $\mathrm{x}$ & & & \\
\hline \multicolumn{12}{|l|}{ HYPERICACEAE } \\
\hline Vismia type & $\mathrm{x}$ & $\mathrm{x}$ & $\mathrm{x}$ & $\mathrm{x}$ & $\mathrm{x}$ & $\mathrm{x}$ & $\mathrm{x}$ & $\mathrm{x}$ & $\mathrm{x}$ & $\mathrm{x}$ & 6.30 \\
\hline \multicolumn{12}{|l|}{ MALPIGHIACEAE } \\
\hline Byrsonima type & & & & & $\mathrm{x}$ & & & & & & \\
\hline \multicolumn{12}{|l|}{ MALVACEAE } \\
\hline Bombax munguba & $\mathrm{x}$ & $\mathrm{x}$ & $\mathrm{x}$ & $\mathrm{x}$ & $\mathrm{x}$ & $\mathrm{x}$ & $\mathrm{x}$ & $\mathrm{x}$ & $\mathrm{x}$ & $\mathrm{x}$ & 0.40 \\
\hline \multicolumn{12}{|l|}{ MELASTOMATACEAE } \\
\hline Miconia type & $\mathrm{x}$ & $\mathrm{x}$ & $\mathrm{x}$ & $\mathrm{x}$ & $\mathrm{x}$ & $\mathrm{x}$ & $\mathrm{x}$ & $\mathrm{x}$ & $\mathrm{x}$ & $\mathrm{x}$ & 74.1 \\
\hline \multicolumn{12}{|l|}{ MYRTACEAE } \\
\hline Eugenia type & & $\mathrm{x}$ & $\mathrm{x}$ & & & & & & & & \\
\hline Myrtaceae type & $\mathrm{x}$ & & & & & & & & $\mathrm{x}$ & & 0.02 \\
\hline PASSIFLORACEAE & & & & & & & & & & & \\
\hline Passiflora type & $\mathrm{x}$ & & & & & & $\mathrm{x}$ & & & $\mathrm{x}$ & \\
\hline POLYGONACEAE & & & & & & & & & & & \\
\hline Triplaris type & $\mathrm{x}$ & $\mathrm{x}$ & $\mathrm{x}$ & $\mathrm{x}$ & $\mathrm{x}$ & $\mathrm{x}$ & $\mathrm{x}$ & $\mathrm{x}$ & $\mathrm{x}$ & $\mathrm{x}$ & 0.38 \\
\hline SAPINDACEAE & & & & & & & & & & & \\
\hline Cupania type & & $\mathrm{x}$ & $\mathrm{x}$ & $\mathrm{x}$ & $\mathrm{x}$ & $\mathrm{x}$ & $\mathrm{x}$ & $\mathrm{x}$ & & & 0.06 \\
\hline Serjania type & & & & & & & & & & $\mathrm{x}$ & \\
\hline SOLANACEAE & & & & & & & & & & & \\
\hline Solanum type & $\mathrm{x}$ & $\mathrm{x}$ & $\mathrm{x}$ & $\mathrm{x}$ & $\mathrm{x}$ & $\mathrm{x}$ & $\mathrm{x}$ & $\mathrm{x}$ & $\mathrm{x}$ & $\mathrm{x}$ & 0.94 \\
\hline INDETERMINATE & & & & & & & & & & & \\
\hline Type 1 & & $\mathrm{x}$ & & & & $\mathrm{x}$ & $\mathrm{x}$ & & & & 0.28 \\
\hline Type 2 & & & & $\mathrm{x}$ & & & & & & & 0.06 \\
\hline Type 3 & & & & & & & $\mathrm{x}$ & & & & 0.04 \\
\hline
\end{tabular}

${ }^{*}$ Grains small in size, 3 -colporate; exine perforate.

${ }^{* *}$ Grains intermediate in size, 3 -colporate; exine perforate.

${ }^{* * *}$ Grains intermediate in size, 3 -colporate; exine psilate. 


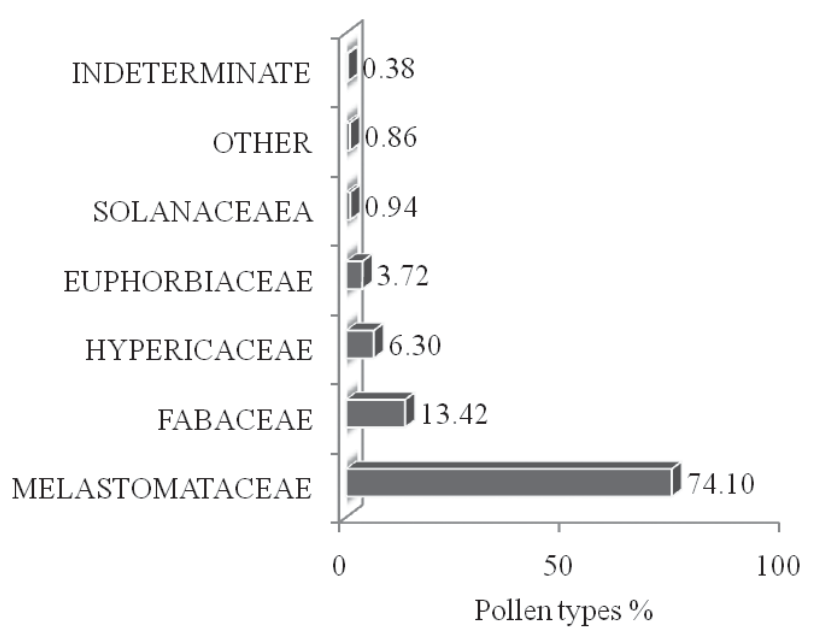

Figure 1. Distribution (\%) of pollen types, by family, in samples of post-emergence residue of the stingless bee Melipona interrupta Latreille. October-November 2010, state of Amazonas, Brazil.

\section{Discussion}

Despite the short sample collection period, this modified protocol showed great viability, producing rapid and conclusive results for the pollen collected from the post-emergence residue of Melipona interrupta, bypassing some of the steps of the acetolysis method proposed by Erdtman (1960), which are paramount to visualizing detailed characteristics of the pollen grain wall. The exposure of the pollen grain to an acidic medium was not necessary in this case, because it already undergoes a similar process in the digestive system of the larvae.
Many protocols applied, for studies and identification of pollen collected by bees, work separately, collecting only the pollen from the pollen basket (Oliveira et al 2009; Ferreira et al 2010), in regurgitated nectar, in pollen pots or in honey (Rech \& Absy 2011a; Rech \& Absy 2011b). In two separate studies, Dórea et al. $(2009 ; 2010)$ studied the post-emergence residue of Centris tarsata Smith. In the protocol applied by those authors, the pollen had to be separated from the sediment. In the present study, we separated only pollen from wax, making it possible to quickly and accurately identify the pollen types contained in the post-emergence residue of Melipona interrupta.

The efficiency of our "adapted" protocol was evidenced by the low frequency of indeterminate pollen in the samples. In addition, we demonstrated that certain types of pollen are not digested by the larvae, as was the case for the pollen grains of Mimosa pudica, which is often foraged by workers of this species, as previously shown (Marques-Souza 1996). This might be related to the extremely small size of the $M$. pudica pollen grain (Erdtman 1952), coupled with the low frequency in the studied samples. However, in order to fully understand this phenomenon, further studies, involving longer sample collection periods and larger numbers of samples, are needed, especially for other bee species.

Our study shows the importance of the Fabaceae family (Mimosoideae), which had a high number of attractive species in times of flowering, thus expanding the trophic niche of the bee. Other species, such as Alchornea (Euphorbiaceae), Schizolobium amazonicum (Fabaceae: Caesalpinioideae), Miconia (Melastomataceae), Solanum type (Solanaceae) and Vismia (Hypericaceae), were present
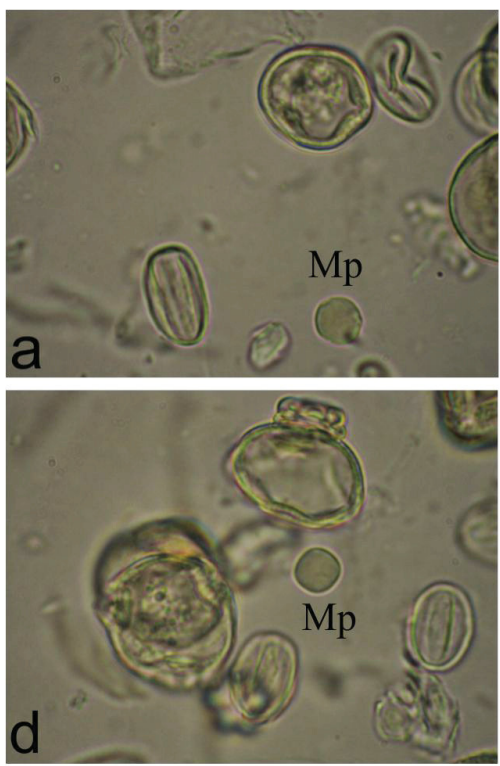
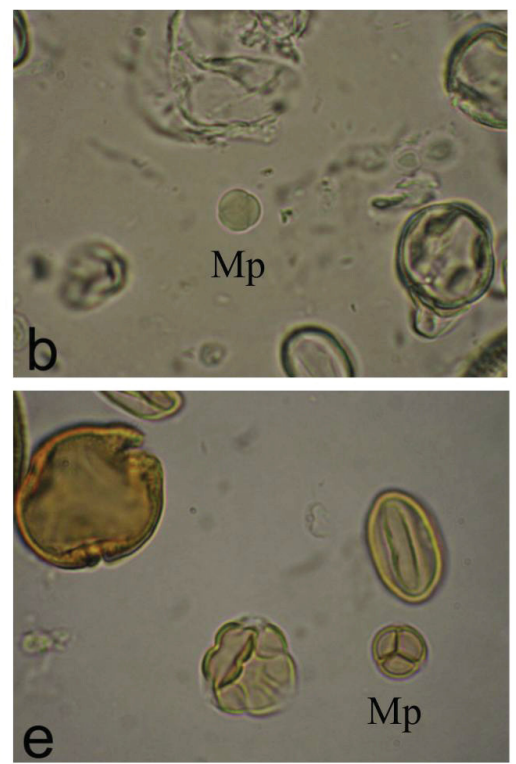
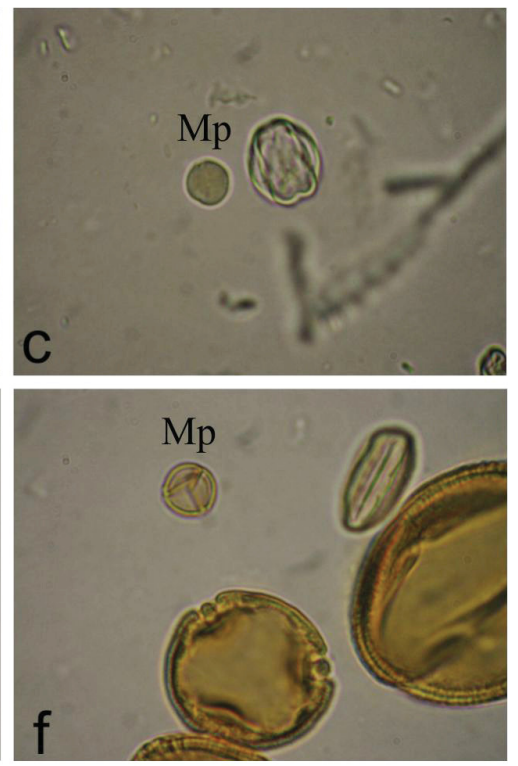

Figure 2. Photomicrographs of pollen grains obtained from the post-emergence residue of Melipona interrupta Latreille, detailing pollen grains of Mimosa pudica (Mp), which retained its content (a-d), in slides prepared in accordance with the modified protocol (a-d) and slides prepared by the acetolysis method (e,f). Scale $=10 \mu \mathrm{m}$. 
in several samples, underscoring their importance for the maintenance of the colony. Overall, the Melastomataceae family was the most representative in terms of pollen types. Melastomataceae is widely distributed in the region and is well represented in numerous studies of stingless bees in the Amazon (Marques-Souza et al. 1995; Marques-Souza 1996; Marques-Souza et al. 1996; Marques-Souza et al. 2002; Oliveira et al. 2009).

Stingless bees are widely distributed in the Amazon, where many species are bred by beekeepers, who can use knowledge of the floral resources used by these bees for the maintenance of colonies and the improvement of stingless bee pasture. The protocol evaluated here enables the identification of the pollen collected, stored and digested by these bees, providing accurate information about the origin and use of trophic resources, in a timely manner.

\section{Acknowledgements}

The authors are grateful to the Brazilian Instituto Nacional de Pesquisas da Amazônia (INPA, National Institute for Amazonian Research) for providing access to the necessary infrastructure, as well as to the Associação Nordesta Reflorestamento e Educação (Associação NORDESTA, Association for Reforestation and Education in Northeastern Brazil), for the technological support provided. This study received financial support from the Brazilian Conselho Nacional de Desenvolvimento Científico e Tecnológico (CNPq, National Council for Scientific and Technological Development; General Research Grant no. 477127/2011-8 and Scholarship Grant no 142459/2011-9 to MGF).

\section{Reference}

Absy, M.L.; Bezerra, E.B. \& Kerr, W.E. 1980. Plantas nectaríferas utilizadas por duas espécies de Melipona da Amazônia. Acta Amazonica 10: $271-281$.

Absy, M.L.; Camargo J.M.F.; Kerr, W.E. \& Miranda, I.P.A. 1984. Espécies de plantas visitadas por Meliponinae (Hymenoptera:Apoidea), para coleta de pólen na região do médio Amazonas. Revista Brasileira de Biologia 44: 227-237.

Absy, M.L. \& Kerr, W.E. 1977. Algumas plantas visitadas para obtenção de pólen por operárias de Melipona seminigra merrillae em Manaus. Acta Amazonica 7: 309-315.

Carvalho, C.A.L.; Moreti, A.C.C.C.; Marchini, L.C.; Alves, R.M.O. \& Oliveira, P.C.F. 2001. Pollen spectrum of "Uruçu" bee (Melipona scutellaris Latreille, 1811). Revista Brasileira de Biologia 61: 63-67.

Dórea M.C.; Santos F.A.R.; Lima L.C.L. \& Figueroa L. 2009. Análise Polínica do Resíduo Pós-emergência de Ninhos de Centris tarsata Smith (Hymenoptera: Apidae, Centridini). Neotropical Entomololy 38: 197-202.
Dórea, M.C.; Aguiar, C.M.L.; Figueroa, L.E.R.; Lima, L.C.L. \& Santos, F.A.R. 2010. Pollen residues in nests of Centris tarsata Smith (Hymenoptera, Apidae, Centridini) in a tropical semiarid area in NE Brazil. Apidologie 41: 557-567

Erdtman G (1952) Pollen Morphology and Plant Taxonomy: Angiosperms. Waltham, Chronica Botanica Co.

Erdtman, G. 1960. The acetolysis method. A revised description. Upsala Svensk Botanisk Tidskrift 54: 561-564.

Ferreira, M.G.; Manente-Balestieri, F.C.D. \& José, B.P. 2010. Pólen coletado por Scaptotrigona depilis (Moure) (Hymenoptera, Meliponini), na região de Dourados, Mato Grosso do Sul, Brasil. Revista Brasileira de Entomologia 54: 258-262.

Imperatriz-Fonseca, V.L.; Kleinert-Giovannini, A. \& Ramalho, M. 1993. Flores e Abelhas em São Paulo. São Paulo, Edusp/FAPESP.

Luz, C.F.P.; Thomé, M.L. \& Barth, O.M. 2007. Recursos tróficos de Apis mellifera L. (Hymenoptera:Apidae) na região de Morro Azul do Tinguá, Estado do Rio de Janeiro. Revista Brasileira de Botânica 30: 29-36.

Marques-Souza, A.C. 1996. Fontes de pólen exploradas por Melipona compressipes manaosensis (Apidae, Meliponinae), abelha da Amazônia Central. Acta Amazonica 26: 77-86.

Marques-Souza, A.C.; Absy, M.L.; Kerr, W.E. \& Aguilera-Peralta, F.J. 1995. Pólen coletado por duas espécies de Meliponíneos (Hymenoptera: Apidae) da Amazônia. Revista Brasileira de Biologia 55: 855-864.

Marques-Souza, A.C.; Miranda, I.P.A.; Moura, C.O; Rabelo, A. \& Barbosa, E.M. 2002. Características morfológicas bioquímicas do pólen coletado por cinco espécies de meliponineos da Amazônia Central. Acta Amazonica 32: 217-229.

Marques-Souza, A.C.; Moura, C.O. \& Nelson, B.W. 1996. Pollen collected by Trigona williana (Hymenoptera, Apidae) in Central Amazonia. Revista de Biologia Tropical 44: 567-573.

Maurizio, A. \& Louveaux, J. 1965. Pollens de plantes mellifères d'Europe. Union des groupements apicoles français, Paris.

Novais, J.S.; Lima, L.C.L. \& Santos, F.A.R. 2009. Botanical affinity of pollen harvested by Apis mellifera L. in a semi-arid area from Bahia, Brazil. Grana 48: 224-234.

Oliveira, F.P.M.; Absy, M.L. \& Miranda, I.S. 2009. Recurso polínico coletado por abelhas sem ferrão (Apidae, Meliponinae) em um fragmento de floresta na região de Manaus, Amazonas. Acta Amazonica 39: 505-518.

Punt, W.; Hoen, P.P.; Blackmore, S.; Nilsson. S. \& Le Thomas, A. 2007. Glossary of pollen and spore terminology. Review of Palaeobotany and Palynology 143: 1-81.

Rech, A.R. \& Absy, M.L. 2011a. Pollen sources used by species of Meliponini (Hymenoptera: Apidae) along the Rio Negro channel in Amazonas, Brazil. Grana 50: 150-161

Rech, A.R.\& Absy, M.L. 2011b. Pollen storages in nests of bees of the genera Partamona, Scaura and Trigona (Hymenoptera: Apidae) along the Rio Negro channel in Amazonas, Brazil. Revista Brasileira de Entomologia 55: 361-372.

Roubik, D.W. \& Moreno, J.E. 1991. Pollen and Spores of Barro Colorado Island. Monographs in Systematic Botany from the Missouri Botanical Garden 36: 1-300.

Salgado-Labouriau, M.L. 1973. Contribuição à palinologia dos cerrados. São Paulo, Academia Brasileira de Ciências.

Wodehouse, R.P. 1935. Pollen grains, their structure, identification and significance in science and medicine. London, McGraw- Hill- Book Company, Inc. 